\title{
Reorienting the Study of Citizenship in Sri Lanka
}

\author{
Nira Wickramasinghe
}

\section{Introduction}

Knowledge production on the concept of 'citizenship' in Sri Lanka has suffered firstly from the anglophilia of most research in the social sciences undertaken in the postcolonial period. Unlike in the French republican tradition where the 'citoyen' and its relation to the state is at the center of all political thought, British political thought gives precedence to the individual and his/her rights per se. Historical circumstances too, namely the Tamil insurrection in the North and East of the country further oriented scholars towards research directly related to what became known as the 'national issue', the 'ethnic issue' or simply the conflict. In many ways the intrusion of the 'here and the now' compounded by sponsored research in the new field of conflict resolution determined the course and the frames of intellectual inquiry in Sri Lanka as well as its gaps and shortfalls from the late 1970s. This was simply not the right time for studies on citizenship to flourish.

In many other locations however, recent decades have witnessed a remarkable upsurge of interest among policy makers and thinkers alike, on both the rights and status of ethno-cultural minorities in multi-ethnic societies (the minority rights/multiculturalism debate) ${ }^{1}$ and the virtues, practices and responsibilities of democratic citizenship (the citizenship-civic virtue debate). To a large extent these two debates developed independently of one another until the 1990s when scholars began to acknowledge the need to attend to both the claims of ethno-cultural minorities and promotion of responsible democratic citizenship. The deeply ingrained mutual distrust between these two lines of inquiry took time to fade away. While those sensitive to minority rights equated civic claims to statist authoritarian moves, promoters of democratic citizenship were suspicious of appeals to minority rights which they saw as reflecting the sort of politics 
of narrow self-interest that they sought to overcome. Transcending this divide, Bhikku Parekh (2000) has argued for a citizenship that is based on institutionally embedded multi-cultural practices rather than assimilation or mere tolerance that would entail a social space for recognition of difference and commonality.

In Sri Lankan scholarship the second component, namely 'citizenship' is virtually absent from public discourse. The obvious reason for the elusive presence of citizenship is, as previously mentioned, the inevitable invasion in every sphere of peoples lives of issues of nationalism, subnationalism and conflict in the past thirty years owing to the Tamil insurrection in the North and East of the island. In the 1980s and 1990s while the world was embroiled in debates over cosmopolitan and multicultural citizenship Sri Lankan studies were concerned with issues of power and democracy and remained locked in outdated analytical frameworks of nation, ethnicity, and community. For historical reasons citizenship has not had in the Sri Lankan scholarly field the seminal and near obsessive presence that nation and state have occupied. Another reason may be that liberal and radical scholars - defenders of minority rights - have been suspicious of majoritarian appeals to some ideal of 'good citizenship' where minorities will eventually be expected to play by majority rules.

Although by the 1990s the term had become a buzzword amongst thinkers in the North, citizenship remained in fact one of the least theorized notions in Sri Lankan studies where a generally instrumental understanding of the term that includes common defense of personal freedom, establishment of basic conditions of social justice and maintenance of civil peace prevails. In Sri Lanka, the tie between citizenship and nationhood, however, can never be wholly deconstructed or ignored. In this light, this paper will proposes future possible areas of study.

\section{Approaches to the study of citizenship}

\section{From TH Marshall to Will Kymlicka}

The concept of citizenship is usually linked with the writing of sociologist Thomas Humphrey Marshall (1950) who defined it as a status which is enjoyed by a person who is a full member of a community. He famously divided citizenship into three dimensions: civil rights, political rights and social rights.

Civil rights are necessary for individual freedoms and are institutionalized in the law courts. Political citizenship guarantees the right to participate in the exercise of political power in the community, either by voting, or by holding political office. Social citizenship is the right to participate in an appropriate standard of living; this right is embodied in the welfare and educational systems of modern societies. The important feature of Marshall's theory was his view that there was a permanent tension or contradiction between the principles of citizenship and the operation of the capitalist market. Capitalism inevitably involves inequalities between 
social classes, while citizenship involves some redistribution of resources, because of rights which are shared equally by all.

T. H. Marshall's well-known evolutionary account of the emergence of social citizenship from political and civil citizenship has been criticized from numerous angles. Among the critiques are that the account fails to describe the emergence of social rights in countries outside of England; that each moment in the extension of citizenship rights has been won through intense struggles and counter-movements; that social rights have become umbrellas for group privileges; above all that the translation of civil and political equality into social rights of the welfare state has been superseded by the need to accommodate a variety of excluded groups into citizenship.

After Marshall, academic discussion of citizenship faded away and political theorists in the 1970 s and 1980s focused primarily on what John Rawls called the 'basic structure' of society: constitutional rights, political discussion making procedure, social institutions. In the 1990s the writings of Kymlicka (1995) took citizenship studies in a new direction that linked the two separate focuses mentioned earlier: issues of cultural rights and civic responsibilities, more precisely multiculturalism and group rights. A few years later the social capital concept most famously utilized by Putnam was adopted by many development agencies as the new way to understand society.

For Will Kymlicka in his Multicultural Citizenship (1995) liberalism was either inadequate or unable to consider group rights within its model. His analysis is rooted in contemporary social analysis in that it examines the ethnic and racial diversity of societies, and the increasing connection among these societies (with modern forms of transportation and communication). These increased connections have raised the issues of identity and rights to the forefront in social movements, individual experiences, and in public policy. Kymlicka considers the nature of the individual and of culture; the meaning of freedom, liberty, the good life; the connection between the individual and culture, groups and society; and the nature of society as a whole. He develops an analysis that leads to policy implications and to implications for the way that we look at ourselves and others, and how we as individuals, and in groups and in society, relate to each other. In societies that will be increasingly diverse in terms of ethnicity in the next century, these are especially important issues to consider.

Putnam's study (1993).looked at how governments functioned differently having the same or identical institutions. He made the point that what was different was the 'civic virtue' or what he terms social capital which is the ability to trust, the willingness to participate and a sense of justice. What he argued in effect was that the health and stability of a modern democracy depends not only on the justice of its institutions but also on the qualities and attitudes of its citizens. Ben Fine, (2001) in his Social Capital versus Social Theory: Political Economy and Social Science at the Turn of the Millennium refuted the notion of social capital 
- meaning capital as a product of social relations which enhances the well-being of the individual or group -. as a highly contentious concept based on an overtly economic understanding of society.. His criticisms of social capital highlight its functional approach, lack of aims at social change, ahistorical and acultural premise, misrepresentation of the social by viewing the social and non-social as two separate entities which are unrelated, renewed attempt at establishing rational choice theory, and the cure all social theory.

When reflecting on citizenship it is useful to acknowledge that there are in fact, as the etymological development of the concept itself demonstrates, several distinct forms of citizenship. The nature of citizenship can be passive or active, depending on whether citizenship is developed from above (via the state) or from below (in terms of more local participatory institutions, such as trade unions). The second dimension is the relationship between the public and the private arenas within civil society. A conservative view of citizenship (as passive and private) contrasts with a more revolutionary idea of active and public citizenship. By combining these two dimensions in the Sri Lankan situation, it would be possible to produce a historically dynamic theory of types of democratic polities where citizenship rights are realized.

\section{Citizenship in Sri Lanka: A historical/legal framework}

The study of citizenship in Sri Lanka has very seldom engaged with some of the international academic debates that I mentioned earlier and has remained a very localized and historically grounded area of research. Research on the theme of citizenship in post independence Sri Lanka has been influenced by two critical events that have shaped the approach adopted and the general questions asked by scholars. The first event is the disenfranchisement of a large part of the population following the passing of citizenship and franchise legislation in 1948 and 1949 and the second is the Tamil insurgency founded on the premise that citizenship rights bestowed by the Constitution were not distributed evenly among all communities of the island.

On gaining independence the new nation state hurriedly passed citizenship and franchise legislation. The Ceylon Citizenship Act No 18 of 1948 created two types of citizenship - citizenship by descent and citizenship by registration. Earlier works on citizenship have studied how the new laws altered the balance of power between the various communities and helped consolidate a majority within the polity (Weerawardena, 1952; S.U Kodikara, 1965). Through these laws Plantation Tamils were defined as an alien and marginal group. More recent studies have focused on the reasons that led to the adoption of restrictive citizenship laws, highlighting the fear of conservative elites of a potential alliance between leftist forces and the estate population (Shastri, 1999). Anthropological approaches have explored the collective memory of plantation workers and their sense of selfhood (Daniel, 1997). 
The second event that has influenced the manner in which 'citizenship' has informed academic and scholarly works is the ethnic civil war that has engulfed the country since the late 1970s. This particular political situation has ensured that ethnic nationalism - that holds that citizenship is based upon a common cultural identity - prevailed upon civic nationalism where membership is tied to a legal - political definition of society. The debate over multiculturalism unlike in Britain was tied to issues of nationality rather than citizenship. While Bhikku Parekh (1991) argued for a citizenship based on institutionally embedded multicultural practices rather than assimilation or mere tolerance, scholars in Sri Lanka remained tied to the idea of rights and obligations of communities. Citizenship was never conceived as the relevant space for the reorganization of difference and commonality.

Another obstacle to the growth of 'citizenship studies' in Sri Lanka has been the emergence and consolidation of what I feel is one of the most intellectually sterile themes that has now conquered the field of social sciences in Sri Lanka namely the ubiquitous 'conflict resolution' rhetoric. The growth of this field is linked to the need for organizations and institutions that can contribute to the range of activities that have come to be known as 'peace building' among foreign states, and international organizations seeking to encourage political stability and integration into the global economic system. There has been in the last decade an increase in the sponsorship and encouragement of international donors to foster particular models of political transformation and conflict resolution. As a result many political activists took up practices of 'peace-building' as a technical and apolitical answer to the conflict. More damaging has been the entry of this concept into research productions. Knowledge production in Sri Lanka influenced by these frames of analysis has been imitative and unimaginative to say the least ${ }^{2}$. The increasing hegemonic discourse of conflict transformation has been an 'obstacle to any innovative thinking into the power structures and ideological formations that sustain Sri Lankan conflicts'. ${ }^{3}$

\section{Focus on citizenship and identity: Boundaries of nation state drawn through citizenship strictures}

My own interest in citizenship started with an exploration of the way sinhala nationalism had constructed the 'migrant' in the late nineteenth and early twentieth century as the 'other' (Wickramasinghe 2000). I argued that at different times the boundaries between migrant and indigenous people shifted: while in the early twentieth century all non-Aryans were considered alien, in later decades a more complex definition of the 'other " was adopted founded on enumerative and scientific criteria such as period of residence or proof of intention to settle - in consonance with the rational and legal order that was implanted in colonial Ceylon.

My later work on citizenship (Wickramasinghe 2005) explored the politics of nostalgia permeating the Sri Lankan state which is largely 
responsible for the representation of the citizen as a proud and self-sufficient peasant-farmer rooted in his land. In the years that followed independence, although the idea of the 'citizen as peasant' was not openly articulated or expressed in political society, it was at the root of many government policies. This constituted a marked contrast with the 1920s-1930s when the citizen-peasant dyad was clearly stated in political debates over the extension of the suffrage. While in the 1930s people engaged in agriculture constituted a sizeable proportion of the population thus giving some reason for a national identification with the peasant, in the twenty first century less than a third of the people live off the land. Nevertheless the state and political parties of all shades continue to propagate the myth of the citizen-peasant through textbooks, posters, and television advertisements while stressing their moral obligation to exercise power on behalf of the 'peasantry'. The aim today appears to be to foster a sense of nostalgia among those who have abandoned rural life rather than to pander to the feelings and needs of peasants themselves.

In Sri Lanka the dominant idea of citizenship was never- from its inception - conceived as an active political identity nor as a regime of participation in the affairs of the state. A number of reasons can be adduced among which the identification of the archetypical/ archetypal citizen with the paddy cultivator - member of a depoliticized target group - is central. The fact that in the country formal political groupings appealed to cultural belonging rather than to common values rendered the emergence of a universal citizen quite improbable. Even the Left fell prey to this situation. Through these politics of nostalgia citizenship was thus 'imagined' by the postcolonial state both as a device of exclusion and as a 'bounded membership association of people' who share a common relationship to the land... peasants, sons of peasants, and nostalgia sycophants.

The creation of nostalgia for a bygone age where the peasantry was proud, prosperous and embodied all the values that the modern age has destroyed is an on-going process. This vision is still dominant in the state education texts read by children and parents, in popular TV shows and advertisements and in the speeches and policies of populist political parties although 'proud peasants' are today portrayed as forming a community in need of help. The idea of the citizen remains tied up with this representation of the sinhala man as peasant, a vision that stemmed from its early framing as the 'other' of the migrant plantation worker.

Drawing from my own work, Rajasingham Senanayake has explored how the institutional legacy of colonial and postcolonial nationstate building transformed the structure of collective identity by effectively defining and delimiting citizenship and its entitlements such as national identity cards, passports, voting and residency rights, equality before the law etc.. She argues that in the process of ordering and classifying identity and difference among the natives in order to institute representative government and construct the bounds of the emerging nation-state some groups came to be identified as authentic and indigenous and therefore 
entitled to citizenship while others were deemed to be migrant or from the Indian diaspora.

\section{Ontology}

Rohan de Silva in his 'On Being, Nation and Citizenship in Sri Lanka: going beyond the ontological hermeneutics of the Buddhist cosmos', (2004) uses the language of hermeneutics to make a point similar to that articulated in my recent work on migrant identity. He shows how national and individual identity 'in' Sri Lanka is created through constitutional and citizenship laws in such a way as to invoke an internal minority, an 'other' against which identities are formed. Differentiation takes place internally as a process of 'internal civilisation' as cititzenship becomes founded in 'opposition to customary, traditional identities in the making of good citizens. Drawing from the work of Kapferer, De Silva problematizes the nation's origins by arguing that the discourse on citizenship in Sri Lanka is driven by an ontological force traceable to the cosmology of Sinhalese Buddhists. But he claims this relation does not betray the nation's origins since this cosmology in turn relies for its force on the performances of nation and law as represented in debates on citizenship. In these debates one can witness the articulation of a mythic narrative whose structure can be traced back to the ancient Chronicles.

The overtly historical approach taken by scholars writing on citizenship has led them to pay less if any attention to citizenship today in the global age. This constitutes a major gap in the scholarship of citizenship in Sri Lanka which needs to be corrected in future studies.

\section{Resisting Intimations of Global Citizenship: The Sri Lanka state's new role in policing the private sphere}

The realities of globalization give, in my view, the issue of citizenship and private-public domains a new urgency. Sri Lanka is indeed in the throes of this 'obscene culture' (Baudrillard 1993) where the world has become immediate and transparent in that it has both globalized and eliminated the distinction between the public and the private. Commercialism - articulated in Sri Lanka by the the popularity of Sirasa super star - irony and play have replaced elite cultural sensibilities - for example, Sarathchandra's plays. The nationalist state can sense that it in danger of being overridden by powers of global culture and politics that it cannot control. The public domain under state control is diminishing, absorbed by the forces of globalization. Communities of taste, habit and belief are increasingly detached from national contexts. My contention is that the state is attempting to resist the global and this inevitable process which it reads as a decline in standards by entering and immersing itself in the private realm.

In the modern Western imaginaries of the public sphere, the citizen-state and the market - singled out by Charles Taylor - are based on a social contract model of society. In Sri Lanka the general argument 
has been that political imaginaries are based upon a neo-patrimonial model of society where the community/civil society is founded on ethnoreligious groupings, where the state-citizen relationship is characterized by a benevolent ruler (rather than a representative) bestowing grants upon deserving subjects and a constant affinity with a protected and regulated market economy. I would argue that new and other political imaginaries have emerged in recent decades that are contesting this reading

What I feel studies on citizenship in Sri Lanka should address

today is how in recent decades the state has divested some of its traditional responsibilities as purveyor of entitlements to groups and individuals and assumed a new role which entails disciplining the body and mind of its citizens by instilling various cultural and social norms and practices. It would be useful to understand the reinvention of the public and private domains of the citizen by the state, why such a reconfiguration has taken place at this particular moment and explore possible consequences for the state and its citizenry. My hypothesis is that it is the fear of the emergence of global citizenship in Sri Lanka that has led the state to assume new roles.

What is apparent for instance is a shift from a state representing the citizen to a state getting involved in shaping/policing the life and culture of it citizenry: for example the state has begun to monitor a long forgotten excise law which does not permit women to buy alcoholic drinks; the state has decreed that women are not permitted to enter government school premises unless clad in a saree; the state has pronounced that no liquor can be bought and consumed during the week surrounding the Vesak festival; the state has issued pronouncements on what type of food is preferable to consume by nationalist minded citizens... In short the post colonial state in a manner reminiscent of colonial governmentality, is acting on 'society itself, rather than, as in the past, fostering change through institutional reforms.

\section{Future research}

\section{Gendered citizenship}

Because it is a historically masculine and often undemocratic construction, citizenship has become a contested concept. British theorist T. H. Marshall (1950) defined citizenship as full membership in a community. From his perspective, citizenship is a universal construct in which difference is rendered invisible. Marshall's understanding of citizenship as universal is supported by liberal theories of citizenship which reduce it to merely legal status through identification of the rights that an individual holds within the state. Theoretically, all individuals have universal access to these rights by virtue of their membership in a state. Citizenship may also be understood as a series of dichotomies, including public/private, individual/community, male/ female, justice/care, rights/responsibilities, to be a citizen/to act as a citizen, which establish inequities in that one is always valued over the other. 
As the state understanding of citizenship is not gender blind there is a need for a gender based critique of citizenship. In Sri Lanka liberal feminists have fought and are still fighting for a wide range of new rights for women to make them equal citizens as stated in the Constitution, without however challenging the dominant/male model of citizenship and politics. Who a 'citizen' is, what a citizen does, and the arena within which he acts, have been constructed in the masculine image. Although women became citizens at the same time as men, their formal citizenship was won within a structure of patriarchal power in which women's qualities and tasks are still devalued.

Motherhood, the bringing of life, is less valued as the ultimate test of citizenship than the man's willingness to fight, kill and die for his country. In a country at war this phenomenon is particularly acute and is reflected in frequent attempts on the part of the state to recruit young men as soldiers to be sent to the front.

If the present concept of citizenship is a male one, can women's concerns be accommodated within such as framework? Until recently most feminists in Sri Lanka concerned with the contribution that feminism could make to democratic politics have been focussing on specific demands that could express women's interests, neglecting other options. In that sense they have failed to offer a critique of the exercise of citizenship that consists in adopting a universal point of view, made equivalent to Reason and reserved to men (Wickramasinghe, 2006).

Uncovering the false universality behind the term 'individual' seems a prerequisite of any demand for rights from the liberal/male democratic state. But emphasising 'feminine' values and mothering as a test of citizenship is contestable on grounds of essentialism and discrimination towards non reproducing women.

Is there room for new conceptions of citizenship where sexual difference 'should become effectively non-pertinent'?

\section{The political imaginary of peoples: How people understand citizenship,} the link between them and the state, duties and responsibilities.

A recent study of Tissamaharamaya (Wickramasinghe, Leelarathne to be published) has called for a more complex and specific reading of political imaginaries that take into account the creative part played by the recipient as well as the re-constitution of the discourse of Sinhalese nationalism through its encounter with peasant common sense. Through an ethnography of Tissamaharama - a small town in the Southern province of Sri Lanka, located in an overwhelmingly Sinhalese area, where the council is the only local authority in Sri Lanka controlled by the Janata Vimukti Peramuna, a hard-line Sinhalese nationalist party - this paper explores the place occupied by and features of citizenship in the political imaginary of the peasant himself/herself. The hypothesis of this work is that consent is not a passive but an active process and that the peasants' practical reasoning is part of the subjectivization process. This paper shows 
that the different 'repertoires' of subjectivization can feed the political and symbolic discourse/language and addresses the materiality of the political imaginary of the peasant, through a study of his political practices, acts and gestures at various points in time. A more nuanced understanding of politics would emerge from an examination of how the reformer is reformed by its own object - in this instance peasants- or how the receiver changes the message.

\section{Endnotes}

1 Questions of minority rights and diversity have moved to the forefront of political theory. See the works of Kymlicka (2007, 2001, 1995), Charles Taylor (1997), and James Tully (1995).

2 See for instance the reports of the Center for Policy Alternatives and the books produced by the Berghof Foundation for Conflict Studies, Colombo

3 Alan Keenan, The trouble with evenhandedness. On the politics of human rights and peace advocacy in Sri Lanka, (pp88-117) in ed. Non Governmental Politics, Zone Books, 2007, p. 90 


\section{References}

De Silva, R 2004, 'On being, nation and citizenship in Sri Lanka: going beyond the ontological hermeneutics of the Buddhist cosmos', in Peter $\mathrm{F}$ and Patricial $\mathrm{T}$ (eds), Critical beings, law, nation and the global subject, Ashgate, London.

Fine, B 2001, Social capital versus social theory: political economy and social science at the turn of the millennium, Routledge, New York.

Keenan, A 2007, "The trouble with evenhandedness. On the politics of human rights and peace advocacy in Sri Lanka', in Non Governmental Politics, Zone Books, pp. 88-117

Kodikara, S.U 1965, Indo Ceylon relations since independence, Colombo. Kymlicka, W 2007, Multicultural odysseys: navigating the new international politics of diversity, Oxford University Press, New York.

Kymlicka, W 2001, Politics in the vernacular: nationalism, multiculturalism and citizenship, Oxford University Press, New York.

Kymlicka, W 1995, Multicultural citizenship: a liberal theory of minority rights, Oxford University Press, New York.

Marshall, T.H 1950, Citizenship and social class and other essays, Cambridge University Press, Cambridge.

Mouffe, C 1992, 'Feminism, citizenship and radical democratic politics', in J. Butler \& J. Wallach-Scott (eds), Feminists theorize the political, Routledge, New York, pp.369-384.

Parekh, B 2000, Rethinking multiculturalism, Macmillan, London.

Shastri, A 1999, 'Estate Tamils, the Ceylon citizenship act of 1948 and Sri Lankan politics', Contemporary South Asia, vol. 8, no.1, pp. 65-88

Taylor, C 1997, The politics of recognition, Broadview press, Petersborough. Tully, J 1995, Strange multiplicity: constitutionalism in an age of diversity, Cambridge University Press, Cambridge.

Weerawardena, IDS 1952, 'The minorities and the citizenship act', Ceylon Historical Journal, vol. I, no. 3, pp. 242-250.

Wickramasinghe, N 2006, Sri Lanka in the modern age. A History of contested identities, London, C.Hurst.

Wickramasinghe, N 2005, 'Politics of nostalgia. The citizen as peasant', Delhi School of Economics Occasional Papers, New series, no 2.

Wickramasinghe, $\mathrm{N}$ 2000, 'Migration and migrant communities in early twentieth century Sinhala nationalism', in C.Bates (ed.), Community, empire and migration: South Asians in diaspora, Palgrave, London, pp. 153-184.

Wickramasinghe, $\mathrm{N}$ and Leelarathne, $\mathrm{S}$ 'The political imaginary of the 'peasant' citizenship and democracy in Tissamaharamaya', in Niraja G. D (ed.), to be published in a Volume by Routledge, New York.

Yuval-Davis, N. \& Werbner, P 1999, Women, citizenship and difference, Zed Books Ltd, London. 
